\title{
KEPRIYAYIAN TOKOH DALAM NOVEL WARNA LOKAL JAWA DAN SUMBANGANNYA DALAM PENGEMBANGAN KARAKTER BANGSA
}

\author{
Suroso \\ Fakultas Bahasa dan Seni Universitas negeri Yogyakarta \\ email: suroso@uny.ac.id
}

\begin{abstract}
This study aims to describe the upper class characteristics of the characters in novels with the Javanese local color to develop the nation's character. It employed content analysis using the descriptive-analytic technique. The data sources were novels with the Javanese local color representing certain eras. The findings are as follows. First, people belong to the upper class because of inheritance and hard work. Second, there are two categories of upper class people, i.e. traditional ones with Dutch education and Islamic religion and new ones with university education and professional and structural positions. Third, they have good characters. Fourth, the characters of Javanese upper class people can serve as a basis to build and develop the nation's character. Fifth, the character development can be carried out in the family by emphasizing religious attitudes and through humanity knowledge development emphasizing interpersonal, emotional, and spiritual aspects.
\end{abstract}

Keywords: upper class, novels with local color, nation's character

\section{PENDAHULUAN}

Mengamati proses kepemimpinan Indonesia masa kini dapat disimpulkan belum banyak pemimpin yang memiliki kewibawaan. Padahal kewibawaan adalah sesuatu yang mutlak dimiliki oleh seorang pemimpin. Di dalam kewibawaan tersimpan pula sifat-sifat keteladanan, integritas, yang berdimensi ketertiban, disiplin, dan bertanggung jawab. Pernyataan di atas amat kontradiktif dengan keadaan masa kini. Menurut Prof. Dr, Achmad Syafi'i Maarif yang seringkali dikemukakan dalam berbagai kesempatan bahwa kerusakan bangsa ini "sudah hampir sempurna”. Hal yang sama juga dikemukakan oleh Amien Rais bahwa bangsa Indonesia sudah krisis kepercayaan diri.

Kepemimpinan Indonesia masa kini masih diwarnai oleh kekuasaan yang jauh dari nilai-nilai kebijaksanaan dan kemanusiaan. Kepemimpinan masih didominasi oleh praktik-praktik penggalangan massa, kesanggupan untuk berteriak keras, bahkan diperoleh dengan kekerasan. Jika dikaitkan dengan pernyataan Machiavellli (1991) bahwa cara memperoleh kekuasaan yang dilakukan dengan cara kekerasan. Sedangkan kekuasaan yang diperoleh manusia beradab selalu diperjuangkan dengan hukum dan kasih sayang.

Kekuasaan yang diperoleh dengan penumpahan darah dan kekuasan biasanya tidak bertahan lama. Para diktator yang memperoleh kekuasaan demikian sering dijinakkan oleh kejujuran, ketabahan, dan kasih sayang. Demikian juga dengan kekuasaan-kekuasaan yang lain yang diperoleh dengan cara tak beradab juga tidak memiliki nilai keabadian. Tokoh-tokoh humanis seperti Mahatma Gandhi, Nelson Mandela, dan Corazon Aquino telah membuktikannya. 
Apa hubungan antara sifat dan sikap kepriyayian pada novel warna lokal Jawa dengan pendidikan karakter masa kini? Masih relevankah nilai-nilai lama yang dipertahankan oleh para tokoh priyayi dalam novel warna lokal Jawa itu dalam konteks pendidikan dan kepemimpinan nasional? Apakah benar bahwa para priyayi secara genetik keturunan priyayi yang terus diwariskan sifat kepriyayiannya? Apakah priyayipriyayi baru dapat diciptakan? Analisis kepriyayian tokoh dalam novel Warna lokal Jawa dapat menjadi acuan pengembangan pendidikan karakter pada konteks sekolah dan bangsa.

Deskripsi kepriyayian tokoh dalam novel warna lokal Jawa dapat memberi sumbangan dalam pengembangan pendidikan karakter. Dengan melakukan deskripsi dan analisis karater priyayi dalam novel warna lokal Jawa, akan ditemukan sumbangan yang cukup berarti tentang karakter priyayi Jawa yang dapat digunakan sebagai konstruk pengembangan karakter bangsa. Sikap seenaknya sendiri, lemahnya motivasi untuk maju, memperoleh hasil dengan cara mudah, pesimis., dan tiadanya visi yang kuat untuk mewujudkan cita-cita dapat dihadapi dengan sifat-sifat priyayi yang cenderung sabar, sopan, mawas diri, rendah hati, tidak pendendam, rela, jujur, tertib, disipllin, menjaga wibawa dan bertangung jawab.

Penelitian ini secara umum bertujuan mendeskripsikan kepriyayian tokoh dalam novel warna lokal Jawa dan secara khusus mencari relevansi deskripsi tokoh dalam novel warna lokal jawa yang dapat diangkat menjadi materi pengembangan karakter bangsa. Kepriyayian tokoh tercermin dari sikap dan tindakan tokoh dalam menghadapi berbagai pesoalan.

Penelitian ini menjadi penting karena sampai saat ini belum secara eksplisit dirumuskan karakter bangsa berdasarkan korpus penelitian yang didapat dari produk budaya, yaitu karya sastra. Deskripsi kepriyayian dalam novel wrna lokal Jawa pada akhirnya dapat bermanfaat memberi sumbangan beberapa indikator karakter bangsa yang digali dari produk budaya.

\section{METODE}

Penelitian ini menggunakan metode analisis konten. Penelitian tentang karakter priyayi pada umumnya merupakan analisis isi pesan yang tercermin dalam tokoh. Oleh karena itu, penelitian ini bersifat deskriptif yang memerikan tentang sikap dan tindakan yang dilakukan priyayi yang digambarkan oleh novel-novel warna local jawa. Masalah kepriyayian dan hubungannya dengan karakter bangsa itu akan dianalisis dari berbagai dimensi seperti yang tersurat dalam tujuan penelitian

Desain yang digunakan dalam penelitian ini yang merupakan estimasi terhadap gejala yang tedapat pada data. Pola kepriyayian yang akan dideskripsikan menyangkut beberapa gejala, maka parameter yang digunakan juga meliputi beberapa parameter sesuai gejala yang dideskripsikan. Jika diskemakan dapat digambarkan berikut.
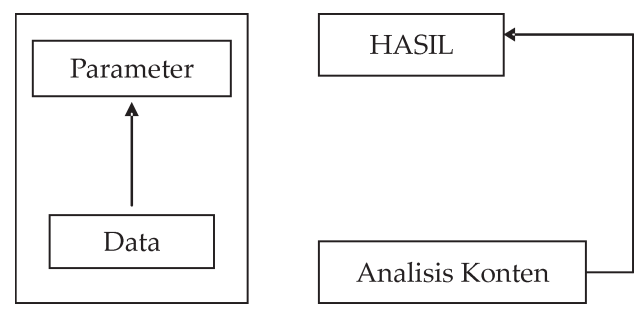

Subjek penelitian ini adalah novel warna lokal Jawa yang memiliki gambaran karakter tokoh priyayi yang terbit pada periode 1980- 2005 yang ditulis oleh para penulis dengan latar budaya jawa yang mewakili zamannya. Rentang waktu 25 tahun untuk menggali apakah ada konsistensi karakter priyayi dalam kurun waktu tersebut. 
Penarikan sample novel dilakukan secara purposif, dibatasi pada tokoh priyayi yang mempengaruhi perkembangan karakter budaya Jawa sehingga kepriyayiannya dapat teridentifikasi secara jelas. Sampel terdiri dari 7 Novel yang dapat mewakili kurun kepriyayian dalam suatu masa tertentu yang mewakili piola kepriyayian Jawa. Ketujuh novel tersebut adalah seperti berikut ini adalah Burung Burung Manyar karya YB Mangunwijaya, Canting karya Arswendo Atmowiloto, Para Priyayi Karya Umar Kayam, Bekisar Merah Karya Ahmad Tohari, Pasar Karya Kuntowijoyo, Tirai Menurun Karya NH Dini, dan Perempuan Yogya karya Achmad Munif..

Pengumpulan data dilakukan dengan teknik pembacan dan pencatatan secara cermat novel yang dijadikan sampling memalui kartu data. Kartu data dibagi dua kelompok yaitu (1) kelompok yang mendeskripsikan tentang sifat dan sikap kepriyayian tokoh dan (2) kelompok yang mendeskripsikan sikap dan tindakan kepriyayian tokoh.

Validitas yang digunakan dalam penelitian ini adalah validitas semantik, jika data yang muncul perihal sifat, sikap dan tindakan kepritayian tokoh memiliki konsistensi dan kesesuaian menggambarkan ucapan, tindakan, dan motivasi yang tercermin dalam karakter kepriyayian tokoh. Reliabilitas yang digunakan dalah reliabilitas interrater, yaitu mengkonsensuskan hasil penelitian dengan pakar sastra dan psikologi.

Data dianalisis dengan teknik analisis konten dengan prosedur (a) pencatatan (recording), (b) reduksi data, (c) pengkategorian, dan (d) inferensi. Pencatatan dilakukan dengan kartu data. Unit data diambil dari unit kata, kalimat, paragrap narasi yang mencerminkan pola kepriyayian. Proses analisisnya dilakukan dengan alur (1) pemahaman isi novel secara keseluruhan, (2) identifikasi pola kepriyayian yang tercermin dalam sifat dan tindakan tokoh, (3) klasifikasi kepriyayian dan kontribusi pemetaan karakter dalam rangka pengembangan karakter bangsa. Setelah klasifikasi data yang belum terstruktur, ditata dan disaring dengan membuang data-data yang kurang relevan dengan tujuan penelitian. Pada tahap inferensi yaitu menginterpretasikan cirri-ciri kepriyayian tokoh yang tercermin dalam sifat dan tindakan tokoh.

Konstruk analisis penelitian ini dijabarkan sebagai berikut. Pertama, pola kepriyayian dalam novel warna lokal Jawa tercermin dari masa novel itu ditulis berdasarkan pandangan penulisnya. Pola kepriyayian itu tercermin dalam sifat, sikap, dan tindakan tokoh. Kedua, untuk menggali pola kepriyayian dalam novel warna local Jawa itu diperlukan pengalaman berupa analisis terhadap karakter tokoh yang tercemin dalam penarasian cerita yang terlihat dalam ucapan, tindakan, dan motivasi tokoh. Ketiga, dengan mengetahui pola kepriyayian yang tercermin dalam analisis perwatakan priyayi Jawa disertai pemahaman konteks sosial budaya Jawa dirumuskanlah suatu kesimpulan dengan memanfaatkan parameter kepriyayian yang telah dirumuskan. Dengan demikian hasil analisis yang dicapai dalam rangka menarik kesimpulan tentang kepriyayian dalam hubungannya untuk mengembangkan karakter bangsa dapat dilakukan

\section{HASIL DAN PEMBAHASAN}

Membaca tokoh-tokoh yang dihadirkan pengarang dalam novel adalah membaca ideologi pengarang dan filosofi yang ingin disampaikan kepada pembaca. Hal ini dapat dijelaskan bahwa sastra merupakan corong filsafat. Ide, pikiran, gagasan pengarang disampaikan melalui tokoh utama yang membawa pesan. Dalam bahasa yang sederhana sastra merupakan media untuk memahami pemikiran-pemikiran filsafat 
dalam tokoh yang digambarkan oleh pengarangnya.

Substansi yang terdapat dalam novel warna lokal Jawa seperti Para Priyayi karya Umar Kayam, Pasar karya Kuntowijoyo, Tirai Menurun karya NH Dini, Burung Burung Manyar karya YB Mangunwijaya, Canting karya Arswendo Atmowiloto, Bekisar Merah karya Ahmad Tohari, , dan Perempuan Yogya karya Achmad Munif dapat mewakili ideologi dan filosofi priyayi Jawa. Melalui analisis tokoh utama dalam novel tersebut dapat dipahami nilai-nilai Jawa, khususnya sifat, perilaku atau tindakan tokoh terhadap tokoh lain serta filsafat yang ingin dikemukakannya.

Filsafat dapat dipahami dalam sastra karena keduanya memiliki dasar pijakan yang sama, yaitu pengalaman atau realitas hidup. Filsafat bertolak dari kenyataan, diabstrasikan, kemudian dicari jati diri dan hakikatnya, maka sastra berawal dari kenyataan yang dibingkai dengan imajinasi dengan memanfaatkan estetika bahasa.

\section{Kepriyayian dalam Masyarakat Jawa}

Secara etimologi istilah priyayi berasal dari kata para dan yayi (para adik) yaitu adik dari. (Kartodirdjo, 1987:2). Dari etimologi rakyat ini sudah mengandung pengertian bahwa istilah priyayi dikaitkan untuk orang-orang terhormat, berwibawa, dan dekat dengan pejabat tinggi. Oleh karena itu, istilah priyayi dikaitkan dengan sekelompok orang dengan status dan kedudukan tertentu, atau kelompok sosial tertentu.

Priyayi adalah golongan sosial yang tertinggi dalam masyarakat perkotaan, yang hidup sebelum Perang Dunia II yang berstatus pergawai negeri (Koentjoroningrat, 1984:234). Terdapat dua jenis priyayi, yaitu priyayi yang pangreh praja dan priyayi yang bukan pangreh praja. Golongan pangreh praja adalah pejabat pemerintah daerah, yaitu priyayi yang paling tinggi gengsinya diantara priyayi lain karena kebangsawanannya. Sedang priyayi jenis kedua, adalah orang-orang terpelajar, yang berasal dari daerah pedesaan atau derah tiyang alit di kota yang berhsil menjdi pegawai negeri karena pendidikan.

Golongan priyayi ini akarnya terletak pada kraton Hindu Jawa sebelum Kolonial. Mereka yang mengembangkan etika kerajaan yang halus, kesenian, tarian, sandiwara, sastra, dan musik. Karena kelompok priyayi ini sebelum Perang dunia II menjdi pemegang kekuasaan, maka pola kebudayaannya pernah menjadi pola umum. Tingkah laku dan pandangan hidupnya menjadi ukuran dan tingkah laku umum yang ideal.

Priyayi dengan sifat kebangsaannya bersifat tertutup, artinya tidak semua orang dapat menjadi anggota kelompok ini. Dalam politik kepegawaian pemerintah Kolonial dikenal asas keturunan. Asas ini menjadi salah satu syarat pengangkatan pegawai, terutama jabatan Wedana ke atas, dan ditegaskan dengan Undang-Undang. Jabatan elite ini tidak mudah ditembus tanpa adanya hubungan kekerabatan.

Priyayi dibedakan priyayi luhur dan priyayi kecil. Priyayi luhur dapat dilihat dari jabatan ayahnya, asal keturunan ibunya, dan asal keturunan isterinya. Priyayi kecil adalah priyayi karena jabatan pada administrasi pemerintah. Perbedaan lain juga terlihat dari rumahnya, pakaian, dan gaya hidupnya. Priyayi kecil ini tidak harus dan tidak tentu keturunan Bangsawan. Mereka yang bersal dari rakyat kebanyakan pun dapat menjdi priyayi karena jasa dan kesetiaannya pada penguasa dan melalui proses panjang. Bagi mereka yang berasal dari rakyat kebanyakan menjadi priyayinya harus melalui lembaga suwiti, ngenger, dan magang ((Kartodirdjo, 1987:7)

Masyarak Jawa membedakan dua golongan sosial yaitu wong cilik dan 
kaum priyayi. Wong cilik adalah sebagian besar petani yang memiliki pendapatan rendah di kota. Kaum priyayi adalah kaum pegawai dan golongan intelektual. Selain dua golongan tersebut terdapat kelompok kaum ningrat (nDrara) yaitu kelompok priyayi yang memiliki prestise cukup tinggi. Yang pandangan dan gaya hidupnya tidak berebda dengan kaum priyayi.

Kaum priyayi bekerja lebih banyak menggunakan pikiran. Termasuk golongan ini adalah guru SD, pegawai kantor pos, dan kereta api di kota kecil. Pegawai menegah dan pegawai tingkat tinggi di kota besar termasuk golongan ini (Suseno, 1987:13). Para priyayi dulu sangat dihormati dan mereka masih berusaha menaikkan geni dengan cara mengawini keluarga bangsawan dan meniru gaya hidup kraton.

Priyayi tradisional di dalamnya termasuk mereka yang memperoleh pendidikan akademik. Pada umumnya mreka memeluk agama Islam. Dari kalangan mereka banyak yang mengikuti paguyuban, yaitu kelompok-kelompok yang mengusahakan kesempurnaan hidup manusia melalui praktik meditasi dn mistik. Para priyayi ini adalah pembawa kebudayaan kota Jawa tradisional di Kraton Yogyakarta dan Surakarta.

Pada tahun 1920-an generasi baru priyayi, terutama yang hidup di kota kecil di kota kabupaten, terdiri dari orang baru yang merupakan tamatan sekolah menengah yang secara teknis menduduki jabatan semiprofesional, seperti dalam bidang kedokteran, guru, pegadaian, pekerjaan umum, dan pelbagai cabang administrasi (Kartodirdjo, 1987:102).

Sebagai kelompok pejabat, para priyayi baru ini berperan sebagai aristokrat lama yang telah turun-temurun menduduki pangkat dalam pangreh praja, sehingga tidk mengherankan apabila mereka menentukan norma-norma kehidupan golongan priyayi. Merekalah yang mengetahui tradisi dan senantiasa menduduki tempat terhormat, dan menjadi titik orientasi pola kehidupan priyayi lain.

Dengan semakin luasnya orang memperoleh pendidikan, maka anakanak petani dan wong cilik terbuka untuk menjdi priyayi. Kesempatan untuk menjadi priyayi baru dapatdilakukan dengan belajar di sekolah negeri, baik yang memakai pengantar bahasa daerah (Sekoah ongko loro) maupun yang memakai bahasa Belanda (HIS) (Kartodirdjo, 1987). Untuk masuk sekolah Belanda penyeleksiannya ditentukan oleh kedudukan orang tua.

\section{Relevansi Sikap Kepriyayian Jawa dan Pengembangan Karakter}

Pak Mantri Pasar adalah tokoh utama novel Pasar karya Kuntowijoyo (1994). Yang dapat mewakili sosok priyayi Jawa. Pak Mantri sebagai tokoh sentral adalah pegawai pemerintah yang taat dengan cara hidup Jawa yang mewakili masyarakat tradisional. Sebagai Mantri Pasar Gemolong ia memiliki tanggung jawab sosial tinggi dan sebagai manusia Jawa yang mistikus ia menerapkan dunia batinnya secara individual. Dalam pergulatannya dengan komunitas pasar, ia terlibat dengan permasalahan pasar yang berkait dengan intrik, rongrongan, dan pemberontakan terhadap jabatannya.

Permasalahan yang dihadapi Pak Mantri adalah dengan para pedagang pasar yang jauh dari nilai-nilai ketertiban. Masalah lain yang dihadapi adalah dengan Kasan Ngali. Pedagang kaya yang pragmatis dan kaya mewakili kapitalisme. Kedua hal yang dihadapi Pak Mantri itu memaksa dirinya untuk mempertahankan nilai-nilai kepriyayian Jawa yang dimiliki, sebagai "senjata" yang dapat digunakan untuk menghadapi permasalahan berkait dengan jabatannya sebagai Mantri Pasar. 
Sifat dan Sikap tokoh Pak Mantri yang berdimensi Kepriyayian Jawa tercermin dari sifatnya yang sabar, sopan, mawas diri, kasih sayang, rendah hati, tidak pendendam, rela, jujur dan setia. Kesabaran Pak mantri tercermin dari interaksinya dengan komunitas pasar yang dipimpinnya. Ia tidak jadi menempeleng Sopir dan Kenek yang berbuat tak senonoh dengan penjual nasi di warungnya. Ia juga tidak marah kepada para pedagang yang memukuli burung dara kesayangannya. Tindakan untuk tidak marah adalah tindakan terpuji, begitu kata hati yang diyakini sebagai orang Jawa. Demikian pula ia tidak akan lelah menasihati orang untuk selalu hati-hati.

Di tengah keriuh-rendahan orang saling berteriak meneriakkan keinginannya, Pak Mantri justru mengajarkan perihal kesopanan. Hendaknya orang tidak terlalu

Sikap priyayi Jawa juga tercermin dari tindakan Sosrodarsono dalam Novel Umar Kayam Para Priyayi. Sikap yang paling ditekankan keluarga priyayi adalah sikap untuk selalu eling. Sifat eling itu menghubungkan detik-detik pengalaman masa lalu dan masa sekarang. Eling bertalian dengan kesadaran diri sendiri yang diutamakan dalam perbuatan. Sumstansi sifat eling diantaranya orang mengurangi makan dan tidur, agar dapat mengurangi hawa nafsu.

Sikap priyayi yang lain adalah mejaga keurukunan. Kekuatan yang mendasari prinsip kerukunan adalah kenyataan bahwa semua yang merasa sehati sejiwa dan tiadanya ketegangan terhadap keluarga dan masyarakat. Dengan sifat rukun orang Jawa mampu berperan untuk bijaksana, dicintai, dan dihormati. Prinsip kerukunan dan persaudaraan tersebut sangat membantu dalam membangun kehidupan masyarakat.

Priyayi Jawa juga memiliki sifat tepa slira dengan sesama. Jika orang menolong, ia yakin jika mendapat ke- sususahan juga ada yang menolongnya. Sikap sepi ing pamrih rame ing Gawe. Sepi ing pamrih berarti menahan diri, tidak mementingkan diri sendiri, apa yang secara positif dilakukan atas dasar sikap yang ditentukan oleh masyarakat. Sikap rame Ing Gawe , berarti giat bekerja. Seseorang dalam melaksanakan tugasnya tidak hanya ingin memperoleh sesuatu, tetapi katena rasa tanggung jawabnya. Bukan karena dipuji yang dapat menimbulkan sikap sombong.

Selain sifat eling, rukun, sepi ing pamrih, rame ing gawe, sifat priyayi Jawa adalah sabar. Dengan kesabaran segala sesuatu akan dapat diatasi

\section{Kategori Menjadi Priyayi}

Kategori cara menjadi priyayi Jawa dibedakan bagaimana dia memperoleh status kepriyayiannya. Priyayi yang bersifat keturunan merupakan priyayi dengan sifat kebangsaan yang tertutup, artinya tidak semua orang dapat menjadi anggota kelompok ini. Dalam politik kepegawaian pemerintah kolonial dikenal asas keturunan. Asas ini menjadi salah satu syarat pengangkatan pegawai, terutama jabatan wedana ke atas, dan ditegaskan dengan undang-undang. Jabatan ini tidak mudah ditembus tanpa adanya hubungan kekerabatan. Dalam Novel Burung-Burung Manyar dijelaskan bahwa Brajamukti adalah keturunan Ayah Keeraton Mangkunegaran berpendidikan Belanda dan ibunya seorang perempuan Belanda. Brajamukti sebagai priyayi ketutunan keraton tidak diperkenankan hidup senenaknya dan harus mematuhi traidisi keningratnnya.

Berbeda dengan Lantip, dalam novel Para Priyayi karya Umar kayam, Ia menjadi priyayi Jawa karena dengan cara mengabdi (suwito) dan kerja keras (disiplin, jujur, dan tanggung jawab). Status priyayi didapatkan juga dari hasil usaha orang-orang desa atau dari daerah tiyang alit terpelajar yang berhasil menjadi pe- 
gawai negeri karena pendidikan. Priyayi ini berasal dari masyarakat kebanyakan yang menjadi priyayi karena jasa dan kesetiannya pada penguasa melalui proses penjang. Bagi mereka yang berasal dari rakyat kebanyakan menjadi priyayi harus melalui lembaga suwito, ngenger, dan magang (Kartodirdjo, 1987:7).

"Nama saya lantip, Ah, tidak. Nama saya yang asli sangatlah dusun dan ndeso. Wage. Nama itu diberikan, menurut embok saya, karena saya dilahirkan pada hari Sabtu Wage. Nama Lantip itu saya dapat kemudian waktu saya mulai tinggal di rumah keluarga Sosrodarsono, di Jalan Setenan, di Kota Wanagalih. Pada hari pertama saya di rumah Setenan itu Ndoro Guru Putri mengajari saya membersihkan kamar-kamar dan mengatut hidangan dan di meja makan. (Para priyayi, 1992: 9, 18-19)"

Jenis Priyayi dalam Novel warna Lokal Jawa mencakup priyayi tradisional berpendidikan akademik, beragama Islam, beserikat dalam paguyuban, penjaga budaya keraton Yogya dan Solo dan Priyayi generasi baru/Jawa baru tamatan Sarjana Muda sampai doktor, punya jabatan profesi (guru, dokter, dosen, pegawai pegadaian, bank) dan punya jabatan stgruktural. Jenis priyayi baru tidak disebut dalam Novel perempuan Yogya karya Ahmad Munif, sebaliknya priyayi tradisional dan priyayi generasi baru disebut dalam novel Burung-Burung Manyar, Canting, Para Priyayi, Pasar, dan Bekisar Merah. Dalam novel Burung-Burung Manyar jenis priyayi yang dipaparkan temasuk priyayi modern, sebaliknya dalam Para Priyayi, Umar Kayam lebih banyak menonjolkan priyayi tradisional. Pandangan pemikiran Priyayi modern tampak ketika Sosrodarsono ikut kelompok yang mengusahakan kesempurnaan hidup.
“Keluarga kami dari kedua belah pihak adalah penganut-penganut agama Islam. Tentu, kami bukan penganut agama Islam yang sangat taat, tetapi kami adalah tetap orangorang Islam. Kami dilahirkan sebagai prang Islam, disunat sebagai orang Islam, dinikahkan sebagai orng Islam, dan akan mati dan disembahyangi sebagai orang Islam. Dan bukankah kamu sudah mengucapkan kalimat syahadat, syarat pengakuan sebagai pemeluk agama Islam? Sedangkan Nunuk, gadis pilihan Handojo itu, datang dari keluarga Katholik yang saya dengar adalah agama yan sangat ketat ikatannya, mungkin sama eratnya dengan agama Islam. Apakah Nunuk akan bersedia dikawinkan secara Islam atau syukur-syukur mau jadi Orang Islam." (Para Priyayi, 1992:143)

\section{Sifat dan Sikap Priyayi Jawa}

Deskripsi sifat dan sikap Priyayi Jawa diantaranya sabar, sopan, mawas diri, kasih sayang, rendah hati, tidak pendendam, rela/ikhlas, jujur, setia, rukun, tepa slira/toleran. Namun, nsifat dominan dari karakter tersenut adalah sabar, kasih sayang, dan toleran. Sifat penyabar orang Jawa itu tampak dalam diri pak Mantri seperti kutipan berikut

"Celaka Pak Mantri sempat melihat kelakuan sopir dan kenek itu. Wah kalau bukan penyabar, laki-laki tua itu pasti sudah menempeleng sopir dan kenek itu. Kurang ajar! Brandal!. Seenaknya mempermainkan perempuan. Kaukira apa penjual nasi itu, he. Menjual nasi, bukan menjual tubuh.Ingin sekali Pak Mantri membuat larangan macam itu di pasarnya. Itu kalau ia bukan penyabar (Pasar 1994:3)

Kecintaan pada Tuhan telah mewujudkan rasa bahwa segala sesuatunya telah diatur oleh yang maha mem- 
beri hidup. Hal ini dilukiskan oleh YB Mangunwijaya dalam Burung-Burung Manyar hilangnya perihal hilangnya barang-barang yang dinilai tidak halal.

"Dan paginya lapor kepada pak Lurah. Lalu menunggu saja, gampang. Kalau sapi atau harta tetap hilang teus, ya sudah. Ya jelas itu kehendakAllah, tetapi itu jarang terjadi. Barangkali sapi atau kalung emas yang tak bermutu lagi, dulu memang tidak halal. (Burung-Burung Manyar, 1981:104)

Kecintaan pada Tuhan juga tercermin dari penyesalan diri Darsa kepada Lasi yang dikhianatinya.

“Benar, katamu. Kukira kamu memang salah. Kamu telah menyakiti istrimu. Kamu juga telahmengabaikan angger-angger, aturan Gusti dalam tatakrama kehidupan. Tetapi jangan terlalu sedih. Sebab kesalahan terhadap Gusti Allah mudah diselesaikan.Gusti Allah jembar pangapurane, sangat luas ampunannya. Kamu akan segera mendapat ampunan bila kamu sungguh-sungguh memintanya. (Bekisar Merah, 1993:112)

\section{Upaya Pengembangan Karakter Ber- dasarkan Karakter Priyayi}

Sumbangan pembentukan karakter bangsa melalui karakter tokoh priyayi dilakukan melalui penekanan hidup religius secara internal maupun interpersonal, pengoptimalan situasi pendukungnya seperti pemahaman kebudayaan, lingkungan masyarakat, dan tersedianya sarana peribadatan.

Penyadaran tentang hakikat hidup, takdir, tampak dalam kepasrahan Ibu Antarna yang kelas sosialnya rendah mantan anak gundik bersuamikan seorang ningrat.

"Sebetulnya ia dan suaminya lebih suka tinggal di Bogor, kora tenang itu, tetapi Bu Antana tahu kedudukannya sebagai anak seorang gundik keraton berdarah rendah yang sudah untung mendapat anugerah dianggap sejajar dengan abang tirinya Mas Hendraningrat. Selain itu, pertimbangan, ada baiknya juga Atik bersekolah di kita pusat pergaulan yang leboih luas dan lebih bermutu, membawa mereka ke Jakarta ini (Burung-Burung Manyar, 1981:41).

Keluarga memiliki andil yang besar dalam menciptakan sifat eling (selalu ingat) akan apa yang terjadi.

"Le, kamu, meski sudah jadi priyayi, jangan lupan akan asal-usulmu. Kacang masa lupa dengan lanjarannya. Rumah tanggamu, meski rumah tangga priyayi, tidak boleh tergantung dari gajimu. Le, jadi priyayi itu orang terpandang di masyarakat, bukan jadi orang kaya. Priyayi itu terpandang kedudukannya, karena kepinterannya (Para Priyayi, 1992:48).

Priyayi Jawa selalu menekankan arti sopan-santun, walaupun sudah berpendidikan tinggi.

"Untunglah anak-anak saya itu, meskipun mulai seenaknya mengemukakan pikiran mereka kepada orang tua, masih terpelihara tatakramanya. Mereka tidak kurang ajar kepada kami, masih sopan, dan bahasa Jawanya masih lengkap. Itu membesarkan hati saya. Setidaknya pendidikan kami di rumah tidak siasia. Pelajaran budi pekerti yang saya masukkan lewat cerita-cerita wayang rupanya ada pe-ngaruhnya (Para priyayi, 1992:81)

Dari kutipan di atas sikap pembentukan karakter keluarga dengtan penekanan hidup religius. Meskipun beda generasi Sosrodarsono merasa bangga hasil didikan keluarganya dan bangga dengan tata karama anak-anaknya yang masih terjaga. 
Pengembangan karakter juga dapat dilihat dari kemampuan pengembangan kecerdasan interpersonal Pak Mantri dalam mengelola pekerjaannya sebagai mantri Pasar. Ia tidak berburuk sangka, bahkan rela mengalah.

“Pak Mantri sampai lama memutar kepala ke kanan dan ke kiri. Dan dari mulutnya timbul penyesalan kepada orang itu. "ko, biarlah. Wani ngalah luhur wekasane. Ingatlah itu. Sekarang kitra kalah, belum berarti besok kalah juga. Sebab salah saleh, siapa bersalah, akan menyerah kalah. Percayalah! (pasar, 1994:151)

\section{SIMPULAN}

Berdasarkan kajian terhadap tujuh novel warna lokal jawa dan sumbangannya terhadap pembentukan karakter bangsa disimpulkan berikut ini. Pertama Kategori menjadi priyayi jawa diperoleh dari keturunan, pemberian dan karena usaha kerja keras mengabdi. Terdapat dua jenis priyayi yaitu priyayi tradisional dan priyayi gerneras baru. Ciri priyayi tradisional berpendidikan Belanda, berserikat dan pengabdi kebudayaan Solo danYogya, sedang priyayi generasi bari diperoleh karena jenjang pendidikan dan profesinya. Kedua, Sikap priyayi jawa yang dapat dijadikan sumbangan dalam pengembangan karakter bangsa antara lain (1) kejujuran, amanah dan kearifan,(2) toleransi, fleksibilitas dan kesatuan, (3) sabar, dan rendah hati, (4) bertanggung jawab, disiplin, dan mencintai Tuhan dan sesama. Ketiga, pengembangan karakter bangsa melalui novel warna lokal jawa dilakukan dengan penekanan hidup religius di keluarga, di masyarakat berdasarkan keteladanan hidup.

\section{UCAPAN TERIMA KASIH}

Artikel ini diangkat dari penelitian mandiri yang dibiayai DIPA UNY tahun 2007. Ucapan terima kasih kepada Prof.
Dr. Suminto A Sayuti sebagai reviewer dan Prof. Dr. Tri Hartiti R sebagai penilai laporan akhir, serta sejawat yang membantu dalam verifikasi dan triangulasi data dan hasil penelitian.

\section{DAFTAR PUSTAKA}

Atmowiloto, Arswendo. 1986. Canting: Jakarta: Grafiti Pers.

Dini, N.H. 1995. Tirai Menurun, Jakarta: Gramedia Pustaka Utama

Geertz, Clifford. 1981. Abangan, Santri, dan Priyayi dalam Masyarakat Jawa. Jakarta: Pustaka Jaya.

Herusatoto, Budiono. 1987. Simbolisme dalam Budaya Jawa. Yogyakarta: PT Hanindita

Hurlock, Elizabeth B. 1981. Child Development. London. McGrw-Hill International Book Company.

Kartodirdjo, Sartono. 1987. Perkembangan Peradaban Priyayi. Yogyakarta : Gama Press.

Kayam, Umar. 1992. Para Priyayi. Jakarta: Grafiti Press.

Koentjaraningrat. 1988. Manusia dan kebudayaan Indonesia. Jakarta: Djambatan.

Kuntowijoyo. 1994. Pasar. Yogyakarta: Bentang

Machiavelli, Nicollo, 1991. Sang Penguasa. Jakarta: Gramedia

Magnis Suseno, Franz. 1994. Etika Jawa: Sebuah Filsafat tentang kebijaksanaan Hidup Jawa. Jakarta: Gramedia.

Mangunwijaya, YB. 1988. Burung-Burung Manyar. Jakarta: Djambatan.

Munif, Achmad. 2000. Perempuan Yogya. Yogyakarta: Navila

Suroso. 2003. Kepriyayian Tokoh dalam Novel Warna Lokal Jawa dan Relevansinya dalam Sikap Hidup. Yogyakarta: Universitas Sanatha Dharma.

Sutrisno, Muji.1995. Filsafat Sastra dan Budaya. Jakarta: Obor.

Tohari, Ahmad. 1993. Bekisar Merah. Jakarta: Gramedia. 